with refractory pemphigus vulgaris. J Dermatolog Treat. 2007;18(5):312-314.

7. Hertl M, Zillikens D, Borradori L, et al. Recommendations for the use of rituximab (anti-CD20 antibody) in the treatment of autoimmune bullous skin diseases. J Dtsch Dermatol Ges. 2008;6(5):366-373.

8. Kim JH, Kim YH, Kim MR, Kim SC. Clinical efficacy of different doses of rituximab in the treatment of pemphigus: a retrospective study of 27 patients. Br J Dermatol. 2011;165(3):646-651.

9. Cianchini G, Corona R, Frezzolini A, Ruffelli M, Didona B, Puddu P. Treatment of severe pemphigus with rituximab: report of 12 cases and a review of the literature. Arch Dermatol. 2007;143(8): 1033-1038.

10. Eming R, Nagel A, Wolff-Franke S, Podstawa E, Debus D, Hertl M. Rituximab exerts a dual effect in pemphigus vulgaris. J Invest Dermatol. 2008;128 (12):2850-2858.

11. Colliou N, Picard D, Caillot F, et al. Long-term remissions of severe pemphigus after rituximab therapy are associated with prolonged failure of desmoglein B cell response. Sci Transl Med. 2013;5 (175):175ra30. doi:10.1126/scitranslmed.3005166.

12. Joly $P$, Mouquet $H$, Roujeau JC, et al. A single cycle of rituximab for the treatment of severe pemphigus. N Engl J Med. 2007;357(6):545-552.
13. Matsukura S, Knowles SR, Walsh S, Shear NH. Effect of a single-cycle alternative dosing regimen for rituximab for recalcitrant pemphigus: a case series of 9 patients [published correction appears in Arch Dermatol. 2012;148[8]:970]. Arch Dermatol. 2012;148(6):734-739.

14. Cianchini G, Lupi F, Masini C, Corona R, Puddu P, De Pità $\mathrm{O}$. Therapy with rituximab for autoimmune pemphigus: results from a single-center observational study on 42 cases with long-term follow-up. J Am Acad Dermatol. 2012;67(4): 617-622.

15. Lunardon L. Adjuvant rituximab therapy of pemphigus: a single-center experience with 31 patients. Arch Dermatol. 2012;148(9):1031-1036.

16. Murrell DF, Dick S, Ahmed AR, et al. Consensus statement on definitions of disease, end points, and therapeutic response for pemphigus. J Am Acad Dermatol. 2008;58(6):1043-1046.

17. Craythorne E, du Viver A, Mufti GJ, Warnakulasuriya S. Rituximab for the treatment of corticosteroid-refractory pemphigus vulgaris with oral and skin manifestations. J Oral Pathol Med. 2011;40(8):616-620.

18. Reguiai $Z$, Tabary $T$, Maizières $M$, Bernard $P$. Rituximab treatment of severe pemphigus: long-term results including immunologic follow-up. J Am Acad Dermatol. 2012;67(4):623-629.
19. Shetty S, Fisher MC, Ahmed AR. Review on the influence of protocol design on clinical outcomes in rheumatoid arthritis treated with rituximab. Ann Pharmacother. 2013;47(3):311-323.

20. Leshem YA, Hodak E, David M, Anhalt GJ, Mimouni D. Successful treatment of pemphigus with biweekly 1-g infusions of rituximab: a retrospective study of 47 patients. J Am Acad Dermatol. 2013;68(3):404-411.

21. Horváth $B$, Huizinga J, Pas $H H$, Mulder $A B$, Jonkman MF. Low-dose rituximab is effective in pemphigus. Br J Dermatol. 2012;166(2):405-412.

22. Kanwar AJ, Tsuruta D, Vinay K, et al. Efficacy and safety of rituximab treatment in Indian pemphigus patients. J Eur Acad Dermatol Venereol 2013;27(1):e17-e23. doi:10.1111/j.1468-3083.2011 .04391.x.

23. Emery P, Mease PJ, Rubbert-Roth A, et al. Retreatment with rituximab based on a treatment-to-target approach provides better disease control than treatment as needed in patients with rheumatoid arthritis: a retrospective pooled analysis. Rheumatology (Oxford). 2011;50 (12):2223-2232.

24. Johnston KM, Bolbocean C, Connors J, Peacock S. Cost-effectiveness of rituximab in follicular lymphoma. Expert Rev Pharmacoecon Outcomes Res. 2012;12(5):569-577.

\title{
NOTABLE NOTES
}

\section{Tungiasis}

\section{"The Greatest Curse That Has Ever Afflicted Africa"}

Fabrizio Vaira, MD; Gianluca Nazzaro, MD; Stefano Veraldi, MD

Because of air travel, diseases formerly restricted to tropical and subtropical areas may also now be observed in countries with temperate climates. Among these diseases, one often underrecognized by Western dermatologists is tungiasis, an infestation caused by penetration in the skin of the gravid female of the flea Tunga penetrans. ${ }^{1,2}$ This infestation occurs in poor communities in South America and Africa and sporadically affects travelers to endemic areas. Medical entomology claims that the South American continent was its original site.

The history of this insidious flea is characterized by curious anecdotes. The first reports date back to the pre-Incan period: artists of the Moringa and Chimu cultures depicted morphological features of $T$ penetrans on ceramic jars. The first contact with Europeans was after the Christopher Columbus's sailors landed in Haiti. They fought against this parasite as well as against the natives until they were "slaughtered" by both. Soon, tungiasis became a very important problem for the colonizing European troops who had no previous experience with this flea. For instance, the Spanish military expedition in Colombia (1538), led by Gonzalo Ximenez de Quesada, was stopped for a long period in Sororoca, a town infested by T penetrans. These soldiers suffered so severely that the walking was very difficult. ${ }^{1}$ Native women had compassion and showed the Spaniards how to remove the imbedded fleas. These ancient methods of extraction of the fleas from the skin are still used in some areas in South America and Africa.

The first scientific description of $T$ penetrans and tungiasis was provided by Aleixo de Abreu in $1623 .{ }^{2}$ Tunga penetrans is one of the few parasites that spread from the Western to the Eastern hemisphere. According to the tra- dition, the British ship Thomas Mitchell, during its 1872-1873 voyage, ${ }^{1,2}$ brought the flea from Brazil to Angola in bags of sand used as ballast. Tunga penetrans spread rapidly along the African West Coasts and sub-Saharan regions following the trading caravans. ${ }^{1}$ The small flea brought Africa to its knees. Indeed, towns and villages were so infested that inhabitants were often forced to leave them. Even though $T$ penetrans did not cause death, it caused painful lesions on the feet that prevented walking. Therefore, people starved because they were unable to work in fields. Lionel Decle, at the end of the 19th century, wrote: "In this village there was not man or woman who was not covered with ulcers... my experience makes me look upon the jigger as the greatest curse that has ever afflicted Africa." ${ }^{3(p 571)}$

Author Affiliations: Department of Pathophysiology and Transplantations, University of Milan, IRCCS Foundation, Cà Granda Ospedale Maggiore Policlinico, Milan, Italy.

Corresponding Author: Gianluca Nazzaro, MD, Department of Pathophysiology and Transplantations, University of Milan, IRCCS Foundation, Cà Granda Ospedale Maggiore Policlinico, Via Pace 9, 20122 Milan, Italy (gianluca.nazzaro@gmail.com)

Correction: This article was corrected online July 29, 2014, for errors in the byline. 1. Heukelbach J, de Oliveira FA, Hesse G, Feldmeier H. Tungiasis: a neglected health problem of poor communities. Trop Med Int Health. 2001;6(4):267-272.

2. Veraldi S, Valsecchi M. Imported tungiasis: a report of 19 cases and review of the literature. Int J Dermatol. 2007;46(10):1061-1066.

3. Decle L. Three Years in Savage Africa. New York, NY: M. F. Mansfield; 1898. 